\title{
Spatially Integrated Social Sciences with Qualitative GIS to Support Impact Assessment in Mining Communities
}

\author{
Alex Mark Lechner ${ }^{1,2, *(\mathbb{D}, \text { John Owen }}{ }^{3}$, Michelle Ang ${ }^{1}$ and Deanna Kemp ${ }^{3}$ \\ 1 School of Environmental and Geographical Sciences, University of Nottingham Malaysia, Semenyih 43500, \\ Malaysia; Michelle.Ang@nottingham.edu.my \\ 2 Regional Water and Land Program, Centre for Water in the Minerals Industry, Sustainable Minerals Institute, \\ The University of Queensland, Brisbane Queensland 4072, Australia \\ 3 Centre for Social Responsibility in Mining, Sustainable Minerals Institute, The University of Queensland, \\ St Lucia, Brisbane, Queensland 4072, Australia; j.owen@uq.edu.au (J.O.); d.kemp@smi.uq.edu.au (D.K.) \\ * Correspondence: alex.lechner@nottingham.edu.my
}

Received: 22 December 2018; Accepted: 20 February 2019; Published: 4 March 2019

\begin{abstract}
Spatially integrated social science is a broad term used to describe the integration of space and place in social science research using Geographic Information Systems (GIS). It includes qualitative GIS approaches, such as geo-ethnology and geo-narratives, which combine qualitative social data with GIS and represent an emerging approach with significant potential for facilitating new insights into the dynamic interactions between mining companies and host communities. Mine operations are unique in their complexity, both in terms of the dynamic and diverse nature of issues and the requirement to integrate knowledge, theories, and approaches from a range of disciplines. In this paper we describe the potential for spatially integrated social science using qualitative GIS to understand the social impacts of mining. We review current literature and propose a framework that incorporates quantitative and qualitative knowledge across social and biophysical domains within a multi-user approach. We provide examples to illustrate how our approach could support past, present, and future assessment of socio-environmental systems in large-scale mining. We conclude by discussing the need for a multi-disciplinary approach to support decision makers and local stakeholders in considering complex social and environmental scenarios.
\end{abstract}

Keywords: mining; resource extraction; social impact; environmental impacts; qualitative GIS; geo-narrative; geo-ethnography; geographic information systems; spatially integrated social sciences

\section{Introduction}

Mining is commonly considered to be the purview of geologists and engineers, although the influence and impacts of resource extraction are felt across social and environmental domains [1,2]. As such, there is a need to consider the effects of resource extraction on the surrounding environment, including biodiversity, water, soil, and local communities, alongside the more traditional concerns of production, cost, and efficiency. Failure to address any one of these can lead to long-term environmental and/or social impacts which, in turn, can affect a company's relationship with host communities as well as the viability of other current and future development opportunities [3-5].

Understanding the linkages between natural and human systems is an important focus for mining and natural resource management disciplines, from conservation to catchment management [6-10]. A better understanding of the interactions between social and environmental systems is crucial in the formulation of sustainable development strategies, especially in the context of mining. Mine operations are unique in their complexity, both in terms of the dynamic and diverse issues associated with planning 
across various environmental and social domains. Therefore, the requirement to integrate knowledge, theories, and approaches from a range of different disciplines makes sustainable mine planning a formidable challenge [2].

Applied research that is focused on the management of mining impacts has addressed and, to some extent, integrated social and environmental dimensions, although predominantly using quantitative approaches [11-14]. However, certain kinds of information and knowledge derived from qualitative methods and data are rarely integrated with quantitative data. For example, when disciplines, such as anthropology, are engaged in the early phases of project development to assist in determining ownership of land and local practices for the use and management of natural resources this information is rarely integrated with quantitative approaches used in the environmental sciences.

Spatially integrated social science is a broad term used to describe the integration of space and place in social science research [15]. Such an approach, embedded within a GIS platform, can link qualitative methods with quantitative social and environmental methods. Examples include "ethno-geographical" and "geo-narrative" approaches. At their simplest, these approaches can be used to build multidisciplinary perspectives drawing on respondents' accounts or qualitative knowledge to triangulate findings with other data [16]. Spatial data can be used to complement ethnographic research, including providing context for interpreting qualitative data and providing a more accessible reading than an extended narrative account [17]. GIS, in effect, provides a platform for linking the diverse kinds of data that are needed to understand the unique challenges associated with mining operations.

Integrating knowledge across environmental and social disciplines is of critical importance for addressing many of the intractable problems associated with mine planning. Applying integrated analyses requires that different types of information are made accessible for people involved in decisions about a mining project. It is important to ensure that decision-making processes involve all relevant stakeholders, including government, local communities, environmental groups, and mining companies [18-20]. Different perspectives contribute diverse knowledge about ecological values and system functionality, which can improve the quality and durability of decisions. Techniques using participatory GIS mapping for engaging stakeholders are one means of facilitating decisions that explicitly account for a plurality of perspectives, trade-offs and relationship sets, and to explore potential outcomes [21,22].

This paper reviews and discusses the potential for spatially integrated social science to understand the social impacts of mining on host communities. We emphasize the unique and essential role that a multi-disciplinary approach can provide when assessing the socio-environmental risks and impacts of mining. We first provide examples of the types of qualitative analyses that have a spatial dimension. We then review the current literature on spatially integrated social science. Finally, we develop a framework that incorporates quantitative and qualitative knowledge across social and biophysical domains, within a multi-user approach. This approach includes a requirement for engagement with local level stakeholders.

\section{Qualitative Analyses and Resource Development}

Kemp and Owen [3] highlight the significance of local-level relationships in resource development processes. These processes include strategies that prioritize local relationships to ensure continuity of access to land for operational purposes [23]. Mining companies maintain these relationships primarily through preferential recruitment and inclusion in supply chains, social investment, and routine stakeholder engagement. Decisions about who to engage, when to engage, or what to engage about all rely, to some extent, on qualitative information. The importance attributed to these decisions, and the consequences that follow, is often under-stated and poorly documented.

Mining operations actively use and rely on qualitative information in their exchanges with internal and external stakeholder groups. The use of qualitative information extends to interpreting the perspectives and expectations of these groups. In an environment in which data is central to both engagement and mine planning processes, the absence of records in data management systems has operational implications. 
Securing and maintaining access to land, for example, is an arena where collecting, storing, analyzing, and presenting qualitative information is critical to mining operations [24]. Community relations functions are responsible for ensuring that companies understand which local level stakeholders have rights and entitlements to land and resources in a project's area of interest and maintain an appreciation of how entitlements are allocated amongst members of the community. Without this type of information managing complex and sensitive issues, such as resettlement and in-migration, becomes problematic [25]. When companies require additional land to expand their operations an inability to discern who holds what kinds of legal and customary rights and entitlements can be the difference between whether a project stalls, proceeds, or proceeds responsibly [26,27].

The case for improvement in the way mining companies approach the collection, storage, and use of this kind of social data is two-fold. Firstly, companies cannot demonstrate their commitment to uphold international safeguard frameworks without relevant data. Under the United Nations Guiding Principles on Business and Human Rights [28], for example, companies are required to exercise human rights due diligence in order to "know and show" that they respect human rights. Secondly, the interface between mining companies and communities is dynamic, with each change in the social and environmental landscape raising new questions and challenges. Not only do these shifting complexities create unique circumstances for social due diligence, they also contribute to an evolving and multi-faceted operating environment for all stakeholders involved. Informed decision making in these contexts implies that companies and other groups are able to access, interpret, and integrate widely diverse types of data.

\section{Review of Concepts}

The spatial dimensions of social phenomenon and their characterization with GIS has been the focus of research in the discipline of geography for many decades $[29,30]$. The notion of "space" provides a platform for combining knowledge about social processes and recognizes the heterogeneity of populations and their interactions across space and time [29]. Amongst the sub-disciplines of social science that recognize the importance of space, qualitative GIS is an emerging field with potential for understanding change in and around resource development projects.

Qualitative GIS has been used across the social scientific sub-disciplines from social work [31] to sociology [32]. Spatial data allows researchers to account for spatial dimensions in assessing when, how, why, and where "location" is relevant [31]. GIS is commonly used in qualitative research through the provision of statistics (e.g., demographic data) associated with specific locations in order to provide a broader sense of the context in which to examine social processes, and to examine patterns and trends of these processes, through maps and other forms of visualization [16,17,31,33,34].

To assess the extent and diversity of research on qualitative GIS we conducted a selective review of the academic literature. We used the keywords "geo-ethnography", "geo-narrative", "grounded visualization", and "qualitative GIS" in Scopus, which returned 74 hits (8 February 2019). Due to the broad nature of the topic area and some authors employing GIS with qualitative methods but not using this terminology [32], it is likely that the keyword search contains omission errors. We then selected 14 papers to represent the diversity of research in this area. Papers stem from diverse subject areas including, nutrition and dietetics [35], environmental science, geography, planning, and development [36] (Table 1). Kwan (2016) describes three distinct qualitative GIS approaches as follows: Geo-ethnography [17], grounded visualization [36], and geo-narrative [16]. We found that articles often use multiple terms, including the three described by Kwan [37], in addition to terms such as "spatial polygamy" [38]. Others use the more general term "qualitative GIS" without describing their paper as based on a specific method.

A diverse range of unstructured or semi-structured qualitative techniques are used with GIS data and / or to create qualitative GIS data. Data gathering techniques can include observation of individuals and their behaviour [36], various forms of surveys and interviews [17,35], ethnographic approaches for recording photographs, text, audio, and video [16,36], and participant accounts of daily routines [17]. 
These data can be coded into a GIS (i.e., made spatial), combined with other spatial data (i.e., through overlay analysis) and visualized in a GIS [39,40]. GIS can also be used for participatory mapping to gather ethnographic spatial data, for example, identifying significant sites and establishing linkages between people and places [41]. Finally, GIS data can provide valuable information to triangulate data from qualitative interviews. For example, MacNell (2018) assesses shopping motivation and strategies by comparing respondents' qualitative assessments with spatial data describing the nearest and most frequented supermarket, where distances were derived through a GIS.

Qualitative GIS moves beyond "data" and "GIS tools"—it aims to enhance our understanding of long-standing qualitative science themes, such as power, belief systems, and cultural practices, which shape the development and experience of complex landscapes. In contrast, quantitative methods emphasize measurement and analysis of causal processes between variables, commonly ignoring the subjectivity associated with observation. For example, Knigge and Cope [36] apply a "grounded visualization" approach, where analyses are exploratory, iterative, and recursive, enabling simultaneous consideration of particular instances and general patterns and encouraging multiple views and perspectives from participants involved in the study. Themes emerge through multiple iterations of "constant comparison" [36]. Kwan and Ding's [16] geo-narrative approach allows for a spatial expression of personal narratives, which incorporate emotional geographies to express lived experience of individuals over time. Narratives composed of sequences of events are analyzed through ethnographic data, such as photos, videos, and audio clips, linked to space using GIS software. Qualitative GIS have also been applied through the lens of feminist geographers, who are committed to understanding differences in context and power [36]. 
Table 1. Review of selected existing qualitative GIS approaches. The subject area and category information was obtained from Scimago (www.scimagojr.com, accessed on 9 December 2018).

\begin{tabular}{|c|c|c|c|}
\hline Title & Subject Area and Category & Journal/Book Name & References \\
\hline $\begin{array}{l}\text { GIS, Ethnography, and Cultural Research: } \\
\text { Putting Maps Back into Ethnographic Mapping }\end{array}$ & $\begin{array}{l}\text { Management Information Systems; } \\
\text { Information systems; Cultural studies; } \\
\text { Political Science and International Relations }\end{array}$ & Information Society & [41] \\
\hline $\begin{array}{l}\text { A Geo-ethnographic Analysis of Low-Income Rural } \\
\text { and Urban Women's Food Shopping Behaviors }\end{array}$ & $\begin{array}{l}\text { Nutrition and dietetics; } \\
\text { Psychology (miscellaneous) }\end{array}$ & Appetite & [35] \\
\hline $\begin{array}{l}\text { Grounded Visualization: Integrating the Analysis of Qualitative and } \\
\text { Quantitative Data Through Grounded Theory and Visualization }\end{array}$ & $\begin{array}{l}\text { Environmental Science; Geography, } \\
\text { planning and development }\end{array}$ & Environment and Planning A & [36] \\
\hline $\begin{array}{l}\text { Extending the Qualitative Capabilities of } \\
\text { GIS Computer-Aided Qualitative GIS }\end{array}$ & Earth and Planetary Sciences (miscellaneous) & Transactions in GIS & [39] \\
\hline $\begin{array}{l}\text { Geo-ethnography: Coupling Geographic Information Analysis } \\
\text { Techniques with Ethnographic Methods in Urban Research }\end{array}$ & $\begin{array}{l}\text { Social Psychology; Cultural Studies Education; } \\
\text { Social Sciences (miscellaneous); } \\
\text { Sociology and Political Science }\end{array}$ & American Behavioral Scientist & [17] \\
\hline $\begin{array}{l}\text { Combining Geographic Information Systems and } \\
\text { Ethnography to Better Understand and Plan Ocean Space Use }\end{array}$ & $\begin{array}{l}\text { Forestry; Tourism, Leisure and Hospitality } \\
\text { Management; Environmental Science } \\
\text { (miscellaneous); Geography, } \\
\text { planning and development }\end{array}$ & Applied Geography & [42] \\
\hline $\begin{array}{l}\text { Methods of Mapping Ethnographic Data on Migration, } \\
\text { Tourism, Labor, and Health Risk in the Dominican Republic }\end{array}$ & $\begin{array}{l}\text { Earth-surface processes; Geography, } \\
\text { planning and development }\end{array}$ & Florida Geographer & [43] \\
\hline $\begin{array}{l}\text { Geo-narrative: Extending Geographic Information Systems for } \\
\text { Narrative Analysis in Qualitative and Mixed-Method Research }\end{array}$ & $\begin{array}{l}\text { Earth-surface processes; Geography, } \\
\text { planning and development }\end{array}$ & Professional Geographer & [16] \\
\hline Qualitative GIS and the Visualization of Narrative Activity Space Data & $\begin{array}{l}\text { Information Systems; Geography, planning and } \\
\text { development; Library and Information Sciences }\end{array}$ & $\begin{array}{l}\text { International Journal of Geographical } \\
\text { Information Science }\end{array}$ & [44] \\
\hline $\begin{array}{l}\text { What Qualitative GIS Maps Tell and don't Tell: } \\
\text { Insights from Mapping Women in Tehran's Public Spaces }\end{array}$ & $\begin{array}{l}\text { Cultural Studies; Geography, } \\
\text { planning and development }\end{array}$ & Journal of Cultural Geography & [45] \\
\hline $\begin{array}{l}\text { A Qualitative Geographical Information Systems } \\
\text { Approach to Explore How Older People Over } 70 \text { years Interact with } \\
\text { and Define their Neighborhood Environment }\end{array}$ & $\begin{array}{l}\text { Public health, environmental and occupational } \\
\text { health; Geography, planning and development; } \\
\text { Social science }\end{array}$ & Health and Place & [46] \\
\hline $\begin{array}{l}\text { Combining Survey Data, GIS and Qualitative Interviews in the } \\
\text { Analysis of Health Service Access for Persons with Disabilities }\end{array}$ & $\begin{array}{l}\text { Public health, } \\
\text { environmental and occupational health }\end{array}$ & BMC International Health and Human Rights & [47] \\
\hline $\begin{array}{c}\text { A New Qualitative GIS Method for } \\
\text { Investigating Neighbourhood Characteristics Using a Tablet }\end{array}$ & Earth-surface processes & Cartographica & [48] \\
\hline $\begin{array}{l}\text { Spatial Polygamy and Contextual Exposures (SPACEs); Promoting } \\
\text { Activity Space Approaches in Research on Place and Health }\end{array}$ & $\begin{array}{l}\text { Social psychology; Cultural studies; Education; } \\
\text { Social Sciences (miscellaneous); } \\
\text { Sociology and Political Science }\end{array}$ & American Behavioral Scientist & [38] \\
\hline
\end{tabular}




\section{Multi-User Integration of Quantitative Environmental and Social Data Within A Qualitative Framework}

Qualitative GIS approaches represent a promising suite of methods for understanding the spatial dimensions and dilemmas associated with mining. We argue that these approaches would be more useful if embedded in, or integrated with, quantitative approaches and supported by community engagement. Quantitative spatial approaches are used to understand land use and environmental change at mine sites, including for planning and assessing rehabilitation, understanding the extent of small-scale and artisanal mining, and monitoring a range of mining environmental impacts [11,49-53]. GIS can be used as a common platform to integrate data across biophysical and social science disciplines, using qualitative and quantitative methods, using shared locational data and presented and communicated through interactive visualization platforms.

Figure 1 represents our conceptual model for linking quantitative and qualitative environmental and social data. Starting from the top right, qualitative social research is used to develop an understanding of an ecologically embedded human experience (Figure 1a). An initial output is to establish the relationship between environmental and community changes (Figure 1b). Ethnographic research can be used to characterize livelihood activities or to build a deep knowledge of how environmental degradation from mining impacts livelihood strategies $[34,54,55]$. These information sources can be used to drive the development of spatial data (e.g. through the creation of research questions) to provide another opportunity to build understanding. From here, spatial analyses provide spatial and temporal quantitative data (Figure 1c). A key output from the spatial analysis is land cover classifications informed by, and created in response to, categories developed through qualitative research (Figure 1d). Integration of the land cover data (and other spatial data) occurs through qualitative GIS methods such as a geo-narrative or geo-ethnography (Figure 1e). For example, the use of a time series of land cover change to support and triangulate local community accounts of mine impacts over time. Finally, these spatial data are used in conjunction with biophysical assessments, such as field assessments of water quality (Figure 1f). The choice of biophysical assessments is, to some extent, driven by the qualitative data such as qualitative interviews with local community members to identify specific locations for water quality assessments. Both quantitative and qualitative social data can be used to inform hypotheses, validate environmental data, and identify the types of environmental data that need to be gathered for biophysical assessments.

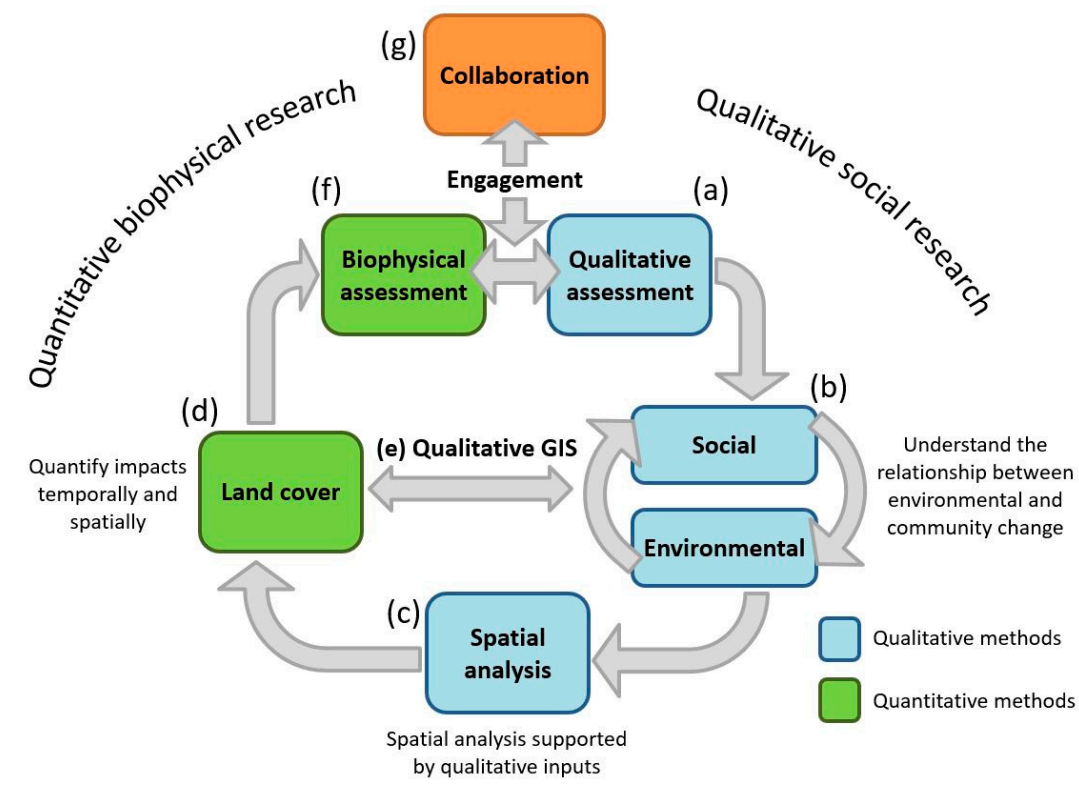

Figure 1. Conceptual diagram describing methods for linking quantitative and qualitative environmental and social data for characterizing mining impacts and local level socio-environmental phenomena. 
Both qualitative and quantitative analyses and the applications of such analyses represent an instrumental approach to decision making where social and biophysical scientists provide data driven assessments of local-scale mining issues. Applications of such approaches can negate the importance of communication and deliberation between a range of stakeholder groups $[56,57]$ who influence and have interests in a mine site's operations. Thus, quantitative and qualitative outputs need to be nested within a communicative and collaborative process to surface deep value conflicts between different communities of practice [58] (Figure 1g). These value conflicts may occur not only between the mining company and the local community but also between parts of a mining company, including between different technical disciplines [59]. Engagement processes recognizing goals, criteria, norms, and knowledge of the various participants can lead to a more personalized understanding of issues and expectations [60-63]. Participatory GIS mapping, as one example, can support collaborative analysis of complex problems and encourage participants to engage with more than one viewpoint or understanding of a given situation. [21,22]. One potential application is participatory scenario development to test values and stakeholder capacities, based on a range of different forecasted outcomes $[20,64]$.

\section{Examples of the Potential Application of Spatially Integrated Social Science to Mining}

Current approaches to investigating the evolution, and prediction, of social and environmental issues associated with mining are limited by their ability to demonstrate the relevance and relationship between key drivers of change. Jacka's [65] Alchemy in the Rain Forest is a recent example that combines methods from political anthropology and remote sensing to explain social and environmental change in a resource development context. To advance knowledge and practice, approaches to the analysis of social and environmental issues must define changes in discipline-specific domains and integrate this information to demonstrate significance within and across the project lifecycle.

There are various ways in which spatially integrated social science, qualitative GIS in particular, could assist research about the impacts of mining. In Table 2 we provide examples showing the potential application of existing qualitative GIS methods to social and environmental issues in mining contexts. 
Table 2. Different methods that could be applied to support assessments of past, present, and future local-scale mining with examples. References from Table 1 describe how similar approaches have been used by in other disciplines.

\begin{tabular}{|c|c|c|c|}
\hline Methods & Present & Future & References (from Table 1) \\
\hline Triangulation & $\begin{array}{l}\text { Spatial data can be used to triangulate qualitative data either during or post- } \\
\text { interview. This can be done for current and historical issues. For example, historical } \\
\text { patterns of mining-induced displacement and resettlement could be mapped using } \\
\text { historical satellite data describing settlement locations to triangulate accounts from } \\
\text { displaced communities (i.e., https:/ / www.youtube.com/watch?v=iNZdryn-zaU). }\end{array}$ & & {$[16,17,33,43]$} \\
\hline $\begin{array}{l}\text { Participatory mapping for } \\
\text { generating new data }\end{array}$ & $\begin{array}{l}\text { Participatory mapping can be used to generate new spatial data from areas of historic } \\
\text { or current importance. For example, participatory mapping can be used to identify } \\
\text { spiritually important locations or customary land boundaries, which are not } \\
\text { commonly recorded on standard maps. }\end{array}$ & & {$[41,42,46,47]$} \\
\hline $\begin{array}{l}\text { Hypothesis/research } \\
\text { question generation }\end{array}$ & $\begin{array}{l}\text { Qualitative assessments are useful for exploratory data analysis, generating hyp } \\
\text { environmental or social impacts which may then be characterized quantitatively with } \\
\text { can be used to identify key environmental concerns of local communities, which are th } \\
\text { social and environmental GIS. }\end{array}$ & $\begin{array}{l}\text { heses, or qualitatively identifying key } \\
\text { patial analysis. For example, focus groups } \\
\text { n assessed and mapped quantitatively with }\end{array}$ & {$[35,44]$} \\
\hline Visualization & $\begin{array}{l}\text { Visualization of social and environmental data can be used as a prop to facilitate an in } \\
\text { land cover change describing the loss and degradation of community lands to mining } \\
\text { be used to illicit responses about how these changes have impact }\end{array}$ & $\begin{array}{l}\text { rview or discussion. For example, maps of } \\
\text { npacts, such as dust and waste storage, can } \\
\text { d on local livelihoods. }\end{array}$ & {$[17,39,43]$} \\
\hline $\begin{array}{l}\text { Integration and data } \\
\text { gathering platform }\end{array}$ & $\begin{array}{r}\text { GIS can be used as a platform for integrating and gathering a diverse array of data t } \\
\text { locations. GPS devices can be used to map daily movement patterns and with qual } \\
\text { infrastructure, such as fences, pipes, and roads, on daily routin }\end{array}$ & $\begin{array}{l}\text { aes and approaches which share common } \\
\text { ative data the negative effects of mining } \\
\text { can be understood. }\end{array}$ & {$[33,36,39,43,45,47]$} \\
\hline $\begin{array}{l}\text { Land use future } \\
\text { scenario generation }\end{array}$ & & $\begin{array}{l}\text { Future land use planning scenarios can } \\
\text { be generated and mapped. For example, } \\
\text { mapped alternative future land use } \\
\text { scenarios can be used as a visual aid to } \\
\text { discuss the implications of future mining } \\
\text { operations and land use configurations. }\end{array}$ & $\begin{array}{l}\text { Examples from outside of the } \\
\text { Qualitative GIS literature }[66,67]^{1}\end{array}$ \\
\hline
\end{tabular}

could be applied using qualitative approaches. 


\section{Conclusions}

The use of GIS for mapping and integrating data about operational and non-operational activities provides a platform for engaging and untangling complex life-of-mine problems. Despite its potential, there are few examples where GIS has been used to integrate qualitative data, beyond enhancing environmental data or combining social and environmental data gathered separately cf. $[11,68]$. Our framework provides some guidance and identifies opportunities for how mining stakeholders can engage across disciplinary domains.

The framework also prompts new engagements in the internal domain of companies, where separation in disciplinary silos is an inherent challenge. Internal collaboration is often limited by the types of data and information each respective discipline is comfortable with. Engineering and environmental sciences are most comfortable using quantitative approaches using biophysical data while community relations and social scientists often work with qualitative data sets. Qualitative GIS provides a link between the disciplines through the use of a common platform and the ability to visualize data across time and space. It also provides a framework for reflecting on power, belief systems, and cultural practices, which shape the data creation and interpretation process from the outset.

Author Contributions: The manuscript was conceptualized and written by A.M.L., J.O. and D.K., M.A. contributed to the literature review and editing the manuscript.

Funding: This research received no external funding.

Conflicts of Interest: The authors declare no conflict of interest.

\section{References}

1. Franks, D.M.; Brereton, D.; Moran, C.; Sarker, T.; Cohen, T. Cumulative impacts: A Good Practice Guide for the Australian Coal Mining Industry; Centre for Social Responsibility in Mining \& Centre for Water in the Minerals Industry, Sustainable Minerals Institute, The University of Queensland: Brisbane, Australia; Australian Coal Association Research: Brisbane, Australia, 2010; ISBN 9780958171021.

2. Lechner, A.M.; McIntyre, N.; Witt, K.; Raymond, C.M.; Arnold, S.; Scott, M.; Rifkin, W. Challenges of integrated modelling in mining regions to address social, environmental and economic impacts. Environ. Model. Softw. 2017, 93, 268-281. [CrossRef]

3. Owen, J.R.; Kemp, D. Social licence and mining: A critical perspective. Resour. Policy 2013, 38, 29-35. [CrossRef]

4. Prno, J.; Slocombe, D.S. A systems-based conceptual framework for assessing the determinants of a social license to operate in the mining industry. Environ. Manag. 2014, 53, 672-689. [CrossRef] [PubMed]

5. Hilson, G. An overview of land use conflicts in mining communities. Land Use Policy 2002, 19, 65-73. [CrossRef]

6. Jakeman, A.J.; Letcher, R.A. Integrated assessment and modelling: Features, principles and examples for catchment management. Environ. Model. Softw. 2003, 18, 491-501. [CrossRef]

7. Lechner, A.M.; Devi, B.; Schleger, A.; Brown, G.; McKenna, P.; Ali, S.; Rachmat, S.; Syukril, M.; Rogers, P. A Socio-Ecological Approach to GIS Least-Cost Modelling for Regional Mining Infrastructure Planning: A Case Study from South-East Sulawesi, Indonesia. Resources 2017, 6, 7. [CrossRef]

8. Virapongse, A.; Brooks, S.; Metcalf, E.C.; Zedalis, M.; Gosz, J.; Kliskey, A.; Alessa, L. A social-ecological systems approach for environmental management. J. Environ. Manag. 2016, 178, 83-91. [CrossRef] [PubMed]

9. Folke, C.; Biggs, R.; Norström, A.V.; Reyers, B.; Rockström, J. Social-ecological resilience and biosphere-based sustainability science. Ecol. Soc. 2016, 21, 41. [CrossRef]

10. Edraki, M.; Baumgartl, T.; Manlapig, E.; Bradshaw, D.; Franks, D.M.; Moran, C.J. Designing mine tailings for better environmental, social and economic outcomes: A review of alternative approaches. J. Clean. Prod. 2014, 84, 411-420. [CrossRef]

11. Schueler, V.; Kuemmerle, T.; Schröder, H. Impacts of surface gold mining on land use systems in Western Ghana. Ambio 2011, 40, 528-539. [CrossRef] [PubMed] 
12. Moran, C.J.; Brereton, D. The use of aggregate complaints data as an indicator of cumulative social impacts of mining: A case study from the Hunter valley, NSW, Australia. Resour. Policy 2013, 38, 704-712. [CrossRef]

13. Petkova, V.; Lockie, S.; Rolfe, J.; Ivanova, G. Mining developments and social impacts on communities: Bowen basin case studies. Rural Soc. 2009, 19, 211-228. [CrossRef]

14. Tuusjärvi, M.; Mäenpää, I.; Vuori, S.; Eilu, P.; Kihlman, S.; Koskela, S. Metal mining industry in Finland-Development scenarios to 2030. J. Clean. Prod. 2014, 84, 271-280. [CrossRef]

15. Goodchild, M.F.; Janelle, D.G. Spatially Integrated Social Science; Goodchild, M.F., Janelle, D.G., Eds.; Oxford University Press, Incorporated: Oxford, UK, 2004; ISBN $9780195348460,9780195152708$.

16. Kwan, M.P.; Ding, G. Geo-narrative: Extending geographic information systems for narrative analysis in qualitative and mixed-method research. Prof. Geogr. 2008, 60, 443-465. [CrossRef]

17. Matthews, S.A.; Detwiler, J.E.; Burton, L.M. Geo-ethnography: Coupling geographic information analysis techniques with ethnographic methods in urban research. Int. J. Geogr. Inf. Geovis. 2005, 40, 75-90. [CrossRef]

18. Voinov, A.; Bousquet, F. Modelling with stakeholders. Environ. Model. Softw. 2010, 25, 1268-1281. [CrossRef]

19. Reed, M.S. Stakeholder participation for environmental management: A literature review. Biol. Conserv. 2008, 141, 2417-2431. [CrossRef]

20. Everingham, J.-A.; Rolfe, J.; Lechner, A.M.; Kinnear, S.; Akbar, D. A proposal for engaging a stakeholder panel in planning post-mining land uses in Australia's coal-rich tropical savannahs. Land Use Policy 2018, 79, 397-406. [CrossRef]

21. Mendoza, G.A.; Martins, H. Multi-criteria decision analysis in natural resource management: A critical review of methods and new modelling paradigms. For. Ecol. Manag. 2006, 230, 1-22. [CrossRef]

22. Lesslie, R. Mapping our priorities-Innovation in spatial decision support. In Innovation for 21st Century Conservation; Figgis, P., Fitzsimon, J., Irving, J., Eds.; Australian Committee for IUCN Inc.: Sydney, Australia, 2012; pp. 156-163.

23. Owen, J.R. Social license and the fear of Mineras Interruptus. Geoforum 2016, 77, 102-105. [CrossRef]

24. Bainton, N.A.; Banks, G. Land and access: A framework for analysing mining, migration and development in Melanesia. Sustain. Dev. 2018, 26, 450-460. [CrossRef]

25. Bainton, N.; Vivoda, V.; Kemp, D.; Owen, J.; Keenan, J. Project-Induced in-Migration and Large-Scale Mining: A Scoping Study; The University of Queensland: Brisbane, Australia, 2017.

26. Kemp, D.; Owen, J.R. A Third Party Review of the Barrick/Porgera Joint Venture off-Lease Resettlement Pilot: Operating Context and Opinion on Suitability; The University of Queensland: Brisbane, Australia, 2015.

27. Gilberthorpe, E.; Banks, G. Development on whose terms?: CSR discourse and social realities in Papua New Guinea's extractive industries sector. Resour. Policy 2012, 37, 185-193. [CrossRef]

28. UN-United Nations Guiding Principles on Business and Human Rights: Implementing the United Nations "Protect, Respect and Remedy" Framework; UNHCR: Geneva, Switzerland, 2011.

29. Goodchild, M.F.; Anselin, L.; Appelbaum, R.P.; Herr Harthorn, B. Toward spatially integrated social science. Int. Reg. Sci. Rev. 2000, 23, 139-159. [CrossRef]

30. Anselin, L. The future of spatial analysis in the social sciences. Geogr. Inf. Sci. 1999, 5, 67-76. [CrossRef] [PubMed]

31. Skinner, D.; Matthews, S.A.; Burton, L. Combining ethnography and GIS technology to examine constructions of developmental opportunities in contexts of poverty and disability. In Discovering Successful Pathways in Children's Development: Mixed Methods in the Study of Childhood and Family Life; Weisner, T.S., Ed.; University of Chicago Press: Chicago, IL, USA, 2005; pp. 223-239.

32. Teixeira, S. Qualitative geographic information systems (GIS): An untapped research approach for social work. Qual. Soc. Work 2016, 17, 9-23. [CrossRef]

33. Rucks-Ahidiana, Z.; Bierbaum, A.H. Qualitative spaces: Integrating spatial analysis for a mixed methods approach. Int. J. Qual. Methods 2015, 14, 92-103. [CrossRef]

34. Jacka, J.K. The Impact of Mining Development on Settlement Patterns, Firewood Availability and Forest Structure in Porgera. In Tropical Forests of Oceania: Anthropological Perspectives; Bell, J.A., West, P., Filer, C., Eds.; ANU Press: Canberra, Australia, 2015; pp. 95-127.

35. MacNell, L. A geo-ethnographic analysis of low-income rural and urban women's food shopping behaviors. Appetite 2018, 128, 311-320. [CrossRef] [PubMed]

36. Knigge, L.D.; Cope, M. Grounded visualization: Integrating the analysis of qualitative and quantitative data through grounded theory and visualization. Environ. Plan. A 2006, 38, 2021-2037. [CrossRef] 
37. Kwan, M.P. Geo-Narrative or Geo-Narratives. Available online: http://meipokwan.org/Geonarrative.html (accessed on 11 December 2018).

38. Matthews, S.A.; Yang, T.C. Spatial Polygamy and Contextual Exposures (SPACEs): Promoting Activity Space Approaches in Research on Place and Health. Am. Behav. Sci. 2013, 57, 1057-1081. [CrossRef] [PubMed]

39. Jung, J.K.; Elwood, S. Extending the qualitative capabilities of GIS: Computer-aided qualitative GIS. Trans. GIS 2010, 14, 63-87. [CrossRef]

40. Fielding, N.; Cisneros-Puebla, C. CAQDAS-GIS Convergence Toward a New Integrated Mixed Method Research Practice? J. Mixed Methods Res. 2009, 3, 349-370. [CrossRef]

41. Brennan-Horley, C.; Luckman, S.; Gibson, C.; Willoughby-Smith, J. GIS, ethnography, and cultural research: Putting maps back into ethnographic mapping. Inf. Soc. 2010, 26, 92-103. [CrossRef]

42. Sullivan, C.M.; Conway, F.D.L.; Pomeroy, C.; Hall-Arber, M.; Wright, D.J. Combining geographic information systems and ethnography to better understand and plan ocean space use. Appl. Geogr. 2015, 59, 70-77. [CrossRef]

43. Livingston, K.; Padilla, M.; Scott, D.; Colón-Burgos, J.F.; Reyes, A.M.; Varas-Díaz, N. Methods of mapping ethnographic data on migration, tourism labor, and health risk in the Dominican Republic. Fla. Geogr. 2016, $47,1-8$.

44. Mennis, J.; Mason, M.J.; Cao, Y. Qualitative GIS and the visualization of narrative activity space data. Int. J. Geogr. Inf. Sci. 2013, 27, 267-291. [CrossRef] [PubMed]

45. Bagheri, N. What qualitative GIS maps tell and don't tell: Insights from mapping women in Tehran's public spaces. J. Cult. Geogr. 2014, 31, 166-178. [CrossRef]

46. Milton, S.; Pliakas, T.; Hawkesworth, S.; Nanchahal, K.; Grundy, C.; Amuzu, A.; Casas, J.P.; Lock, K. A qualitative geographical information systems approach to explore how older people over 70 years interact with and define their neighbourhood environment. Health Place 2015, 36, 127-133. [CrossRef] [PubMed]

47. Eide, A.H.; Dyrstad, K.; Munthali, A.; Van Rooy, G.; Braathen, S.H.; Halvorsen, T.; Persendt, F.; Mvula, P.; Rød, J.K. Combining survey data, GIS and qualitative interviews in the analysis of health service access for persons with disabilities. BMC Int. Health Hum. Rights 2018, 18, 26. [CrossRef] [PubMed]

48. Schoepfer, I.; Rogers, S.R. A New Qualitative GIS Method for Investigating Neighbourhood Characteristics Using a Tablet. Cartogr. Int. J. Geogr. Inf. Geovis. 2014, 49, 127-143. [CrossRef]

49. Isidro, C.M.; McIntyre, N.; Lechner, A.M.; Callow, I. Applicability of earth observation for identifying small-scale mining footprints in a wet tropical region. Remote Sens. 2017, 9, 945. [CrossRef]

50. Lei, K.; Pan, H.; Lin, C. A landscape approach towards ecological restoration and sustainable development of mining areas. Ecol. Eng. 2016, 90, 320-325. [CrossRef]

51. Latifovic, R.; Fytas, K.; Chen, J.; Paraszczak, J. Assessing land cover change resulting from large surface mining development. Int. J. Appl. Earth Obs. Geoinf. 2005, 7, 29-48. [CrossRef]

52. Bao, N.; Lechner, A.M.; Johansen, K.; Ye, B. Object-based classification of semi-arid vegetation to support mine rehabilitation and monitoring. J. Appl. Remote Sens. 2014, 8, 083564. [CrossRef]

53. McKenna, P.; Erskine, P.D.; Lechner, A.M.; Phinn, S. Measuring fire severity using UAV imagery in semi-arid central Queensland, Australia. Int. J. Remote Sens. 2017, 38, 4244-4264. [CrossRef]

54. Owen, J.; Muriuki, G.; Kemp, D. Livelihoods, Food Security and Mining-Induced Displacement and Resettlement; The University of Queensland: Brisbane, Australia, 2018.

55. Adam, A.B.; Owen, J.R.; Kemp, D. Households, livelihoods and mining-induced displacement and resettlement. Extr. Ind. Soc. 2015, 2, 581-589. [CrossRef]

56. Habermas, J. The Theory of Communicative Action; Beacon Press: Boston, MA, USA, 1984

57. Habermas, J. Political communication in media society: Does democracy still enjoy an epistemic dimension? The impact of normative theory on empirical research. Commun. Theory 2006, 16, 411-426. [CrossRef]

58. Raymond, C.M.; Kenter, J.O.; Plieninger, T.; Turner, N.J.; Alexander, K.A. Comparing instrumental and deliberative paradigms underpinning the assessment of social values for cultural ecosystem services. Ecol. Econ. 2014, 107, 145-156. [CrossRef]

59. Kemp, D.; Owen, J.R. The industrial ethic, corporate refusal and the demise of the social function in mining. Sustain. Dev. 2018, 26, 491-500. [CrossRef]

60. Blackmore, $\mathrm{C}$. What kinds of knowledge, knowing and learning are required for addressing resource dilemmas?: A theoretical overview. Environ. Sci. Policy 2007, 10, 512-525. [CrossRef] 
61. Armitage, D.; Berkes, F.; Dale, A.; Kocho-Schellenberg, E.; Patton, E. Co-management and the co-production of knowledge: Learning to adapt in Canada's Arctic. Glob. Environ. Chang. 2011, 21, 995-1004. [CrossRef]

62. Wals, A.E.J.; Rodela, R. Social learning towards sustainability: Problematic, perspectives and promise. NJAS Wageningen J. Life Sci. 2014, 69, 1-3. [CrossRef]

63. Reed, M.G.; Godmaire, H.; Abernethy, P.; Guertin, M.A. Building a community of practice for sustainability: Strengthening learning and collective action of Canadian biosphere reserves through a national partnership. J. Environ. Manag. 2014, 145, 230-239. [CrossRef] [PubMed]

64. Reed, M.S.; Kenter, J.; Bonn, A.; Broad, K.; Burt, T.P.; Fazey, I.R.; Fraser, E.D.G.; Hubacek, K.; Nainggolan, D.; Quinn, C.H.; et al. Participatory scenario development for environmental management: A methodological framework illustrated with experience from the UK uplands. J. Environ. Manag. 2013, 128, 345-362. [CrossRef] [PubMed]

65. Jacka, J.K. Alchemy in the Rain Forest: Politics, Ecology, and Resilience in a New Guinea Mining Area; Duke University Press: Durham, NC, USA, 2015.

66. Schmidt, K.; Walz, A.; Martín-López, B.; Sachse, R. Testing socio-cultural valuation methods of ecosystem services to explain land use preferences. Ecosyst. Serv. 2017, 26, 270-288. [CrossRef] [PubMed]

67. Dorning, M.A.; Van Berkel, D.B.; Semmens, D.J. Integrating Spatially Explicit Representations of Landscape Perceptions into Land Change Research. Curr. Landsc. Ecol. Rep. 2017, 2, 73-88. [CrossRef]

68. Cane, I.; Schleger, A.; Ali, S.; Kemp, D.; McIntyre, N.; McKenna, P.; Lechner, A.M.; Dalaibuyan, B.; Lahiri-Dutt, K.; Bulovic, N. Responsible Mining in Mongolia: Enhancing Positive Engagement; Sustainable Minerals Institute: Brisbane, Australia, 2015.

(C) 2019 by the authors. Licensee MDPI, Basel, Switzerland. This article is an open access article distributed under the terms and conditions of the Creative Commons Attribution (CC BY) license (http:/ / creativecommons.org/licenses/by/4.0/). 